\title{
HAPTOGLOBIN TYPES IN PATIENTS WITH JUVENILE RHEUMATOID ARTHRITIS
}

\author{
BY \\ ANDREW C. PEACOCK AND F. PAUL ALEPA* \\ Carcinogenesis Studies Branch, National Cancer Institute and Arthritis and Rheumatism Branch, National Institute \\ of Arthritis and Metabolic Diseases, National Institutes of Health, Bethesda, Maryland
}

Howard and Ansell (1964) have recently reported the distribution of haptoglobin types among their patients with rheumatic disorders. The incidence of haptoglobin type 1-1 reported by these workers for patients with juvenile rheumatoid arthritis was three times that found in their normal population and twice that found in their adult rheumatoid arthritis patients. Since haptoglobin type is a geneticallycontrolled trait (Smithies and Walker, 1955), these findings suggest that genetic factors may be involved in juvenile rheumatoid arthritis, or that this disorder can modify the biochemical expression of the haptoglobin genotype.

Studies designed to confirm and expand these findings would be of interest as it would add insight into the nature of juvenile rheumatoid arthritis, and perhaps provide evidence for selective advantage for the haptoglobin type 2 gene (Smithies, 1964) or alternatively provide evidence for the modification of genetic expression by disease.

The present study reports the haptoglobin type distribution in fifty patients with juvenile rheumatoid arthritis and in both parents of 29 of these patients.

\section{Methods}

Sera were obtained for this study from fifty Caucasian juvenile rheumatoid arthritis patients followed at the National Institute of Arthritis and Metabolic Diseases and from 58 of their parents. The patients included in the present study satisfy the criteria for the diagnosis of juvenile rheumatoid arthritis as suggested by Ansell and Bywaters (1959). The onset of arthritis in all fifty patients had been before the age of 15 , involved at least four joints, and was present for a minimum of 3 months. The age, sex, duration of disease, results of the F II test (Bentonite flocculation test), and stage and functional capacity for this group of patients are given in Table I.

*Present Address: Department of Medicine, Georgetown University Hospital, Washington, D.C.
TABLE I

DISTRIBUTION OF HAPTOGLOBIN TYPES, BY SEX, AGE DURATION, STAGE * AND CLASS* OF DISEASE, AND RESULTS OF F II TEST

\begin{tabular}{|c|c|c|c|c|c|c|}
\hline \multirow{2}{*}{\multicolumn{3}{|c|}{ Clinical Particulars }} & \multirow{3}{*}{$\begin{array}{c}\begin{array}{c}\text { Number } \\
\text { of } \\
\text { Patients }\end{array} \\
17 \\
33\end{array}$} & \multicolumn{3}{|c|}{ Haptoglobin Types } \\
\hline & & & & $2-1$ & $2-2$ & $1-1$ \\
\hline Sex & \multicolumn{2}{|c|}{$\underset{\text { Female }}{\text { Male }}$} & & $\begin{array}{l}13 \\
13\end{array}$ & $\begin{array}{r}2 \\
15\end{array}$ & $\begin{array}{l}2 \\
5\end{array}$ \\
\hline $\begin{array}{l}\text { Age of Onset } \\
\text { of Disease (yrs) }\end{array}$ & \multicolumn{2}{|l|}{$\begin{array}{l}1-8 \\
9-15\end{array}$} & $\begin{array}{l}31 \\
19\end{array}$ & $\begin{array}{r}18 \\
8\end{array}$ & $\begin{array}{r}7 \\
10\end{array}$ & $\begin{array}{l}6 \\
1\end{array}$ \\
\hline $\begin{array}{l}\text { Duration of } \\
\text { Disease (yrs) }\end{array}$ & \multicolumn{2}{|c|}{$\begin{array}{ll}\text { Less than } 1 & \ldots \\
1-4 & \\
\text { More than } 4 & \ldots\end{array}$} & $\begin{array}{l}22 \\
12 \\
16\end{array}$ & $\begin{array}{r}10 \\
6 \\
10\end{array}$ & $\begin{array}{r}10 \\
4 \\
3\end{array}$ & $\begin{array}{l}2 \\
2 \\
3\end{array}$ \\
\hline \multicolumn{3}{|c|}{ Positive F II (Bentonite flocculation) } & \multirow[b]{2}{*}{9} & \multirow[b]{2}{*}{3} & \multirow[b]{2}{*}{4} & \multirow[b]{2}{*}{2} \\
\hline Test $\quad \ldots$ & . & $\cdots \quad \cdots$ & & & & \\
\hline \multirow{2}{*}{$\begin{array}{l}\text { Rheumatoid } \\
\text { Arthritis }\end{array}$} & Stage & $\begin{array}{l}\text { I } \\
\text { II } \\
\text { III } \\
\text { IV }\end{array}$ & $\begin{array}{r}29 \\
8 \\
8 \\
5\end{array}$ & $\begin{array}{r}15 \\
4 \\
4 \\
3\end{array}$ & $\begin{array}{r}11 \\
3 \\
2 \\
1\end{array}$ & $\begin{array}{l}3 \\
1 \\
2 \\
1\end{array}$ \\
\hline & Class & $\underset{\text { III }}{\text { II }}$ & $\begin{array}{r}12 \\
26 \\
7 \\
5\end{array}$ & $\begin{array}{r}7 \\
12 \\
3 \\
4\end{array}$ & $\begin{array}{r}4 \\
11 \\
2 \\
0\end{array}$ & $\begin{array}{l}1 \\
3 \\
2 \\
1\end{array}$ \\
\hline
\end{tabular}

*Steinbrocker and others (1949).

Haptoglobin type determination was made by the method of Queen and Peacock (1966). Photographs of the stained gels were used to provide a record of the haptoglobin typing (Figure, opposite); all analyses were performed on specimens identified by code numbers without knowledge of the clinical data on the patient.

\section{Results}

The results of haptoglobin typing in the subjects in this study are shown in Table II (opposite). The distribution of haptoglobin types in the patients with juvenile rheumatoid arthritis and in 58 of their parents did not differ significantly from that found in a normal U.S. Caucasian population assembled in an earlier study (Queen and Peacock, 1966). In each of the family groups, the haptoglobin type observed in the child was consistent with the haptoglobin types observed in the parents (Table III, opposite). 
TABLE II

DISTRIBUTION OF HAPTOGLOBIN TYPES IN CHILDREN WITH JUVENILE RHEUMATOID ARTHRITIS, THEIR PARENTS AND A NORMAL POPULATION

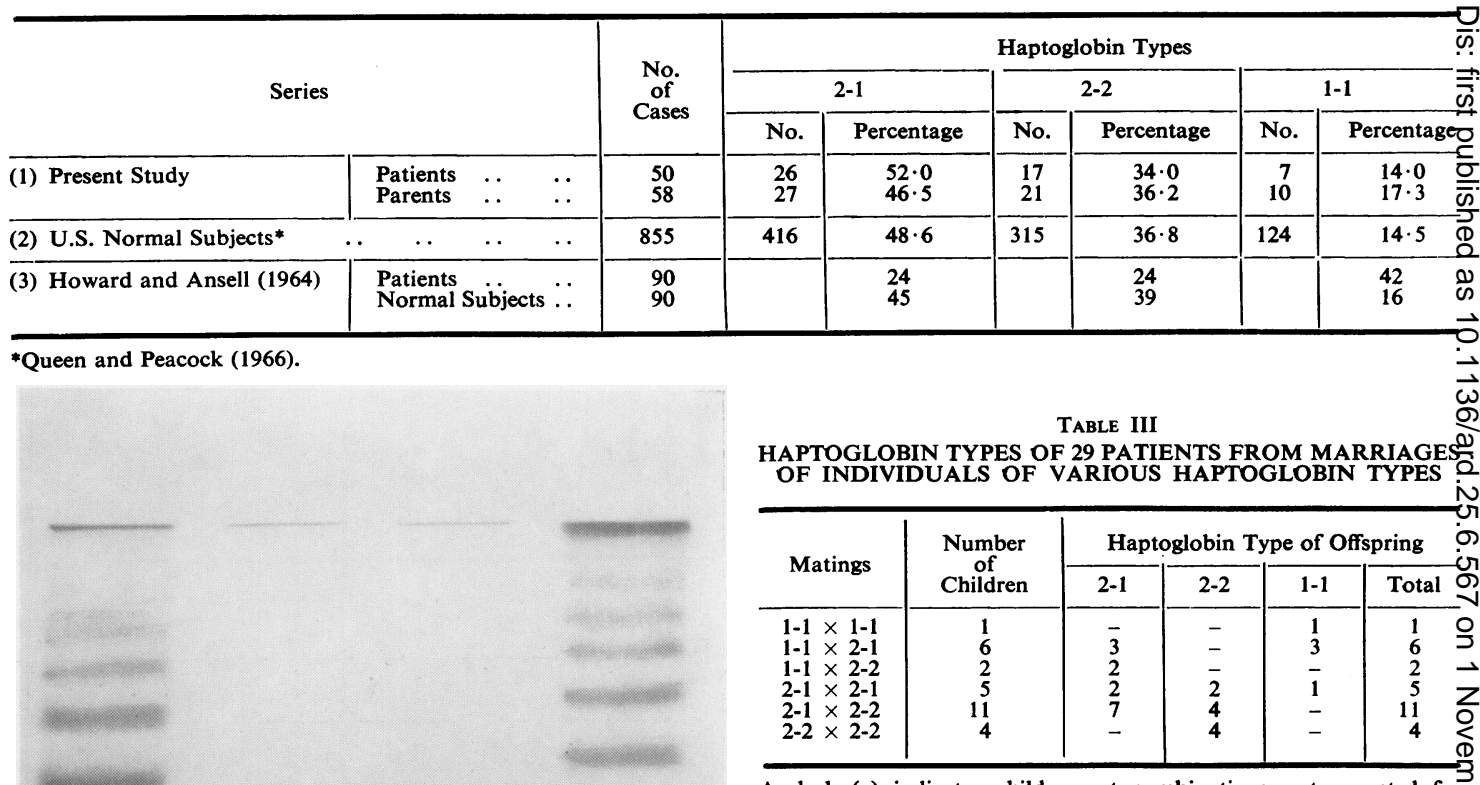

A dash (-) indicates child-parent combinations not expected fo 3 Mendelian inheritance. No children were found in this category

reported by Howard and Ansell (1964) for thoip patients with a similar diagnosis indicates a significant difference between the two populations $\left(x^{2} \% 0\right.$ $11 \cdot 6 ; \mathrm{P}=0.02)$. The distribution in both normak populations, however, are remarkably similar. The causes that may have given rise to such markedly discordant results are not readily apparent.

The results of the present study indicate tha $\overrightarrow{\vec{E}}$ genetic variations in haptoglobin type do not cor 3 relate with a predisposition to the development of juvenile rheumatoid arthritis. However, it is?

Fig.-Representative photograph of haptoglobin typing. Migration is from top to bottom. Identification of haptoglobin types is as follows: (left to right) $2-1,1-1,1-1,2-2$.

\section{Discussion}

An excess of haptoglobin type 1-1 was not observed in the present study in the patients with juvenile rheumatoid arthritis or in their parents. Indeed, the distribution of haptoglobin types in both groups did not differ significantly from the distribution observed in a normal U.S. Caucasian population. In each of the 29 patient-parent groups studied, the haptoglobin type of the patient was concordant with the haptoglobin type of the parents. The pattern of inheritance was wholly consistent with the theoretical expectations based on random marriages and Mendelian inheritance (Galatius-Jensen, 1958) (Table III).

A comparison of the distribution of haptoglobin types found in the present study with the distribution possible that the severity and duration of the disease may depend to some degree on haptoglobin type? Accordingly, the distribution of haptoglobin types ing any series of juvenile rheumatoid arthritis patients may be a reflection of the composition of the group with respect to these factors rather than to the diagnosis alone. No correlation was observed in the present study between haptoglobin type and the sex, age at onset, or duration of disease of patients: with juvenile rheumatoid arthritis (Table I). The series is too small to permit any valid conclusions concerning the relationship of haptoglobin type to the severity of disease or functional capacity (Steinbrocker, Traeger, and Batterman, 1949) of the patients.

The method used by Howard and Ansell (1964) fo the determination of haptoglobin type was not des:cribed and it is, therefore, not possible to discuss the 
differences in technique that might have given rise to the differences in results.

Allison and Blumberg (1958) have reported the haptoglobin type distribution in adult patients with rheumatoid arthritis as follows: (numbers in parentheses are numbers of patients observed in each category) 2-1 (4); 2-2(19); 1-1 (7). When the present results are compared with those of Allison and Blumberg, no statistically significant difference exists between the two populations. Thus, the adult and juvenile forms of rheumatoid arthritis are similar in having a normal haptoglobin type distribution.

The regularity of haptoglobin inheritance in children with juvenile rheumatoid arthritis and the failure to find an abnormal distribution of haptoglobin types in such patients do not, of course, rule out the possibility that there may be genetic features to this disease.

\section{Summary}

Haptoglobin type distribution was determined in fifty patients with juvenile rheumatoid arthritis. In 29 patients, it was shown that the haptoglobin type observed was consistent with the simple Mendelian inheritance of such genes from their parents. In contrast to an earlier report, the distribution of haptoglobin types in patients with juvenile rheumatoid arthritis was found not to differ from that of a normal population.

\section{REFERENCES}

Allison, A. C., and Blumberg, B. S. (1958). Arthr. and Rheum., 1, 239.

Ansell, B. M., and Bywaters, E. G. L. (1959). Bull. rheum. Dis., 9, 189.
Galatius-Jensen, F. (1962). Meth. forensic Sci., 1, 497. Howard, A., and Ansell, B. M. (1964). Ann. rheum. Dis., 23, 232.

Queen, K. G., and Peacock, A. C. (1966). Clin. chim. Acta, 13, 47.

Smithies, O. (1964). Cold Spr. Harb. Symp.quant. Biol., 29, 309.

- and Walker, N. F. (1955). Nature (Lond.), 176, 1265.

Steinbrocker, O., Traeger, C. J., and Batterman, R. C. (1949). J. Amer. med. Ass., 140, 659.

Les types d'haptoglobine observés chez les sujets porteurs d'arthrite rhumatismale juvénile

\section{RÉSUMÉ}

On détermina la distribution des types d'haptoglobine chez 50 sujets atteints d'arthrite rhumatismale juvénile. Chez 29 d'entre eux on montra que le type d'haptoglobine observé était compatible avec le simple mode de transmission héréditaire mendélienne. Contrairement à une communication antérieure, on trouva que la distribution des types d'haptoglobine chez les malades atteints d'arthrite rhumatismale juvénile ne différait pas de celle recontrée dans une population normale.

Tipos de haptoglobina en pacientes con artritis reumatoide juvenil

\section{SUMARIO}

Se determinó la distribución de los tipos de hapto globina en 50 pacientes con artritis reumatoide juvenil. En 29 de ellos fué demostrado que el tipo de haptoglobina observado fué consistente con el simple modo de transmisión hereditaria mendeliana. Contrariamente a una comunicación anterior, la distribución de los tipos de haptoglobina en enfermos con artritis reumatoide juvenil no se distinguía de la encontrada en la población normal. 